\title{
THE STATISTICAL ANALYSIS OF RELATION BETWEEN COMPRESSIVE AND TENSILE/FLEXURAL STRENGTH OF HIGH PERFORMANCE CONCRETE
}

\section{KĘPNIAK ${ }^{1}$, P. WOYCIECHOWSKI ${ }^{2}$}

\begin{abstract}
This paper addresses the tensile and flexural strength of HPC (high performance concrete). The aim of the paper is to analyse the efficiency of models proposed in different codes. In particular, three design procedures from: the ACI 318 [1], Eurocode 2 [2] and the Model Code 2010 [3] are considered. The associations between design tensile strength of concrete obtained from these three codes and compressive strength are compared with experimental results of tensile strength and flexural strength by statistical tools. Experimental results of tensile strength were obtained in the splitting test. Based on this comparison, conclusions are drawn according to the fit between the design methods and the test data. The comparison shows that tensile strength and flexural strength of HPC depend on more influential factors and not only compressive strength.
\end{abstract}

Keywords: high performance concrete, tensile strength, flexural strength, design methods efficiency

\section{INTRODUCTION}

When the tensile stress in a concrete member in building structure exceeds the tensile strength of the concrete, the construction stability declines, this is due to the exposure of the reinforcement to corrosion factors. High performance concrete (HPC) is increasingly used to construct responsible building structures, where stability is one of the key factors. Wider testing and analysis seems to be reasonable, as HPC characteristics differ from those of ordinary concrete. The objective of this paper is to analyse the efficiency of design methods proposed in different codes. The associations

${ }^{1}$ M.Sc., Eng., Warsaw University of Technology, Faculty of Civil Engineering, Al. Armii Ludowej 16, 00-637 Warsaw, Poland, e-mail: m.kepniak@il.pw.edu.pl ${ }^{2} \mathrm{PhD}$., DSc.., Warsaw University of Technology, Faculty of Civil Engineering, Al. Armii Ludowej 16, 00-637 Warsaw, Poland, e-mail: p.woyciechowski@il.pw.edu.pl 
between design tensile strength of concrete obtained from three codes (EC2, ACI 318, Model Code 2010) and compressive strength are compared with the experimental results of tensile strength and flexural strength by statistical tools. Dependence regarding tensile/flexural and compressive strength, shown in standards, has a unified character, which can be related to structural concrete of all types. However, in Eurocodes as well as in Model Code 2010, this dependences varies for concrete classes: $\leq$ C50/60 and HPC. The general character of those does not take into consideration material constituent characteristics and their content in a range of the same strength class. Practical experience and literature overview [4][5] confirm that it is necessary to consider the influence of material constituents, for instance the type and maximal size of aggregates and cement type on the form of dependence tensile/flexural and compressive strength.

The experimental part of the paper presents investigation of HPC samples. The objective of the investigation was to verify the feasibility of use of general dependences in relation to restricted ones, used in a practice range of characteristics of concrete mixture described in section 3.

\section{TENSILE STRENGTH AND FLEXURAL STRENGTH DESIGN METHODS}

\subsection{EUROCODE 2 REGULATIONS}

In European Standard EN 1992-1-1:2004 [2], called Eurocode 2 code the design method for defining tensile strength is provided by the formula (2.1):

$$
f_{c t m}=\left\{\begin{array}{c}
0,30 \cdot f_{c k}^{2 / 3} \text { for } \leq C 50 / 60 \\
2,12 \cdot \ln \left(1+0,1 f_{c m}\right) \text { for }>C 50 / 60
\end{array}\right.
$$

where:

$\mathrm{f}_{\mathrm{ctm}}$ - mean value of axial tensile strength of concrete $[\mathrm{MPa}], \mathrm{f}_{\mathrm{ck}}$ - characteristic compressive cylinder strength of concrete at 28 days [MPa], $\mathrm{f}_{\mathrm{cm}}$ - mean value of concrete cylinder compressive strength [MPa].

Eurocode 2 also gives the association between splitting test results and tensile strength (2.2), however, it does not specify specimen shape.

$$
f_{c t}=0,9 \cdot f_{c t, s p}
$$

where: 
$\mathrm{f}_{\mathrm{ct}}$ - approximate value of the axial tensile strength [MPa], $\mathrm{f}_{\mathrm{ct}, \mathrm{sp}}$ - splitting tensile strength [MPa]

The association between mean flexural tensile strength and mean value of axial tensile strength is formed by means of equation (2.3):

$$
f_{c t m, f l}=\max \left[\left(1,6-\frac{h}{1000}\right) \cdot f_{c t m} ; f_{c t m}\right]
$$

where:

$\mathrm{f}_{\mathrm{ctm}, \mathrm{fl}^{-}}$mean flexural tensile strength of concrete [MPa], $\mathrm{h}$ - total member depth $[\mathrm{mm}], \mathrm{f}_{\mathrm{ctm}}$ - mean value of axial tensile strength of concrete [MPa].

\subsection{ACI 318 REGULATIONS}

According to ACI 318 [1] tensile strength is equated with splitting tensile strength. The standard makes tensile strength dependent on compressive strength, in compliance with equation (2.4):

$$
f_{c t}=6,7 \cdot \sqrt{f_{c}^{\prime}}
$$

where:

$\mathrm{f}_{\mathrm{ct}}$ - splitting tensile strength [psi], $\mathrm{f}_{\mathrm{c}}$ - specified compressive strength of concrete [psi].

It is worth noticing that after converting the unit from psi into $\mathrm{MPa}$, the equation changes into Eq. (2.5):

$$
f_{c t}=0,56 \cdot \sqrt{f_{c}^{\prime}}
$$

where:

$\mathrm{f}_{\mathrm{ct}}$ - splitting tensile strength [MPa], $\mathrm{f}_{\mathrm{c}}$ - specified compressive strength of concrete [MPa].

The value of flexural strength is given by equation Eq. (2.6)

$$
f_{c t m, f l}=(10 \% \div 15 \%) \cdot f_{c}{ }^{\prime}
$$


where:

$\mathrm{f}_{\mathrm{ctm}, \mathrm{fl}}$ - flexural tensile strength of concrete [MPa], $\mathrm{f}_{\mathrm{c}}$ - specified compressive strength of concrete [MPa].

\subsection{Model Code 2010 regulations}

The method implemented in Model Code 2010 [3] is remarkably similar to the method from Eurocode 2. However, some significant differences exist. According to Model Code 2010, tensile strength could be calculated by equation Eq. (2.7):

$$
f_{c t m}=\left\{\begin{array}{c}
0,30 \cdot f_{c k}^{2 / 3} \text { for } \leq C 50 / 60 \\
2,12 \cdot \ln \left(1+0,1\left(f_{c k}+\Delta f\right) \text { for }>C 50 / 60\right.
\end{array}\right.
$$

where:

$\mathrm{f}_{\mathrm{ctm}}$ - mean value of axial tensile strength of concrete $[\mathrm{MPa}], \mathrm{f}_{\mathrm{ck}}$ - characteristic compressive cylinder strength of concrete at 28 days [MPa], $\Delta \mathrm{f}=8 \mathrm{MPa}$.

Association between tensile strength and the result of the splitting test is determined by equation Eq. (2.8):

$$
f_{c t m}=\alpha_{s p} \cdot f_{c t m, s p}
$$

where:

$\mathrm{f}_{\mathrm{ctm}}$ - mean value of axial tensile strength of concrete [MPa], $\mathrm{f}_{\mathrm{ctm}, \mathrm{sp}}$ - splitting tensile strength [MPa], $\alpha_{\mathrm{sp}}=1,0$ conversional factor, chosen as a compromise by authors of the code

The flexure strength is linked to the axial tensile strength by equation Eq. (2.9)

$$
f_{c t m}=\frac{0,06 \cdot h_{b}^{0,7}}{1+0,06 \cdot h_{b}^{0,7}} \cdot f_{c t m, f l}
$$

where:

$\mathrm{f}_{\mathrm{ctm}}$ - mean value of axial tensile strength of concrete $[\mathrm{MPa}], \mathrm{f}_{\mathrm{ctm}, \mathrm{fl}}$ flexure strength of concrete $[\mathrm{MPa}], \mathrm{h}_{\mathrm{b}}$ beam depth $[\mathrm{mm}]$. 


\subsection{Comparison OF Model CODE 2010, ACI 318 AND Eurocode 2 Regulations}

Eurocode 2 [2] and Model Code 2010 [3] do not state the specified value of compressive strength at which the association between tensile strength and compressive strength changes. They subordinate it to concrete strength classes, which is a categorical variable, not a continuous one. Accordingly, the system of equations was solved in order to estimate the limit value, which provided the result $\mathrm{f}_{\mathrm{ck}}=49,7 \mathrm{MPa}$. Once the limit value is exceeded, the growth of compression strength indicates a smaller growth of tensile strength than before the limit value (Fig.1). In the case of flexure strength it is analogous (Fig.1). Equations form the ACI 318 [1], referring to tensile and flexure strength, are independent of compressive strength growth.
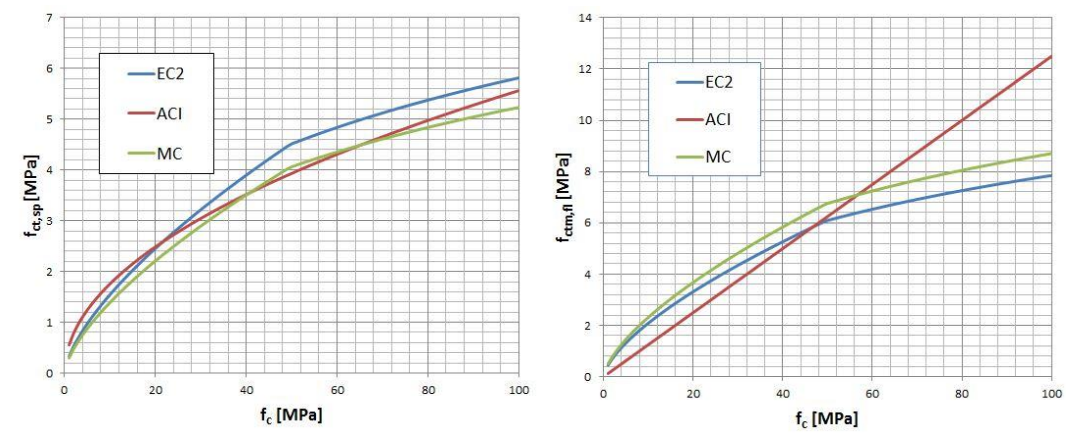

Fig. 1. Tensile splitting (left side) and flexural (right side) vs. compressive strength acc. to different codes

\section{EXPERIMENTAL DATA}

For the statistical analysis of the efficiency of the design methods in determining tensile and flexural strength, the calculated values were confronted with experimental data. The analysis was carried out for specimens of different $\mathrm{w} / \mathrm{c}=0,38 ; 0,43 ; 0,48$. Cement content was constant at 400 $\mathrm{kg} / \mathrm{m}^{3}$. The consistency class also remained constant at $\mathrm{S} 3$. The specimens were constructed from granite aggregates $2 / 16$, bank sand and cement type CEM I $42.5 \mathrm{~N}$. To determinate the compressive strength, procedure form EN 12390-3 [6] was adopted. The tests were performed on cubic, 150x150x150 mm, specimens. In order to determine splitting tensile strength, the procedure from EN 12390-6 [7] was adopted. The tests were performed on cylinders measuring, 150x300 mm, and cubic-150 mm- specimens. In order to determine the flexural strength, the procedure from EN 12390-5[9] was used. The tests were performed on beam-shaped specimens measuring 
100x100x500 mm. Tests were performed in two variants: two-point loading and one-point loading. All specimens were demoulded after $24 \mathrm{~h}$ from casting and cured in water at $\mathrm{T}=20 \pm 2^{\circ} \mathrm{C}$ [8]. For the results, a t-Student test was performed. It proved that there are no significant differences between results obtained for different specimen shapes or different types of loading. The total number of analysed specimens was 45 . The testing of each specimen was performed at the age of 28 days. The obtained test results according to concrete compressive strength are presented in Fig.2.

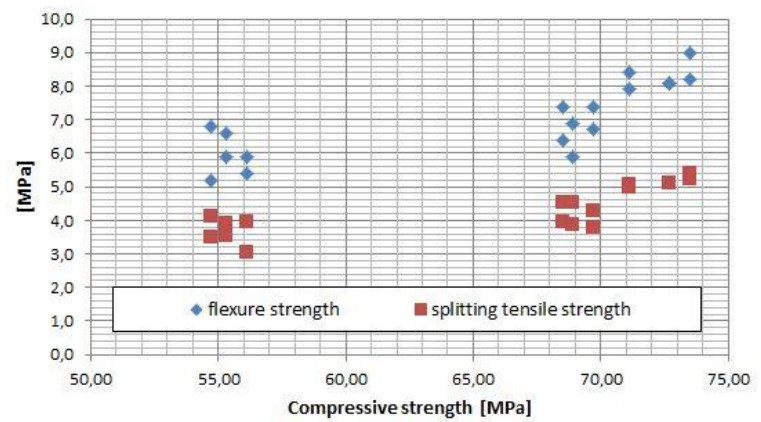

Fig. 2. Splitting tensile and flexure strength versus compressive strength of concrete for experimental data

\section{Statistical ANALYSIS}

The statistical analysis was carried out in two steps: the prediction of dependent variables: $\mathrm{f}_{\mathrm{ctm}, \mathrm{sp}}$ and $f_{f l}$ and the comparison of the acquired regression equation with the design formulas. For prognostic calculations StatSoft's Statistica programme was used. Multiple Regression MR [10] and Generalized Additive Models GAM [11] were applied. In statistical analysis, the partial autocorrelation function and autocorrelation function of the residual number were used [12]. A similar course of action has already been successfully presented by Słowik and Rogalska [13].

\subsection{PREDiCTIONS FOR DEPENDENT VARIABLES: $\mathrm{F}_{\mathrm{CTM}, \mathrm{SP}}$ AND $\mathrm{F}_{\mathrm{FL}}$}

\subsubsection{DATA ANALYSIS}

SI units and abbreviation SI units and data analysis was performed to study the distribution character of the following variables: compressive strength $f_{c}$, splitting tensile strength calculated on the basis of: ACI $318 \mathrm{f}_{\mathrm{ctm}, \mathrm{sp}}{ }^{\mathrm{ACI}}$, Eurocode $2 \mathrm{f}_{\mathrm{ctm}, \mathrm{sp}}{ }^{\mathrm{EC} 2}$, Model Code $2010 \mathrm{f}_{\mathrm{ctm}, \mathrm{sp}}{ }^{\mathrm{MC}}$, flexural strength calculated on the basis of: ACI $318 \mathrm{f}_{\mathrm{fl}}^{\mathrm{ACI}}$, Eurocode $2 \mathrm{f}_{\mathrm{fl}}^{\mathrm{EC} 2}$, Model Code $2010 \mathrm{f}_{\mathrm{fl}}^{\mathrm{MC}}$. 
The Shapiro- Wilk's normality test [11] was performed on the analyzed data. According to summary statistics for every variable coefficient $\mathrm{W}$ was determined and compared with the critical value $\mathrm{W}_{\text {critical }}=0,897$, for the number of observations $\mathrm{N}=18$ and the level of confidence $\alpha=0,05$. Most variables did not have a normal distribution: $\mathrm{f}_{\mathrm{c}}\left(\mathrm{W}=0,771<\mathrm{W}_{\text {critical }}\right), \mathrm{f}_{\mathrm{ctm}, \mathrm{sp}}{ }^{\mathrm{EC} 2}\left(\mathrm{~W}=0,766<\mathrm{W}_{\text {critical }}\right)$, $\left.\mathrm{f}_{\mathrm{fl}} \mathrm{EC}^{\mathrm{EC}} \mathrm{W}=0,766<\mathrm{W}_{\text {critical }}\right), \mathrm{f}_{\mathrm{ctm}, \mathrm{sp}}{ }^{\mathrm{ACI}}\left(\mathrm{W}=0,764<\mathrm{W}_{\text {critical }}\right), \mathrm{f}_{\mathrm{fl}}{ }^{\mathrm{ACI}}\left(\mathrm{W}=0,771<\mathrm{W}_{\text {critical }}\right), \mathrm{f}_{\mathrm{ctm}, \mathrm{sp}}{ }^{\mathrm{MC}}(\mathrm{W}=0,766$ $\left.<\mathrm{W}_{\text {critical }}\right), \mathrm{f}_{\mathrm{fl}}^{\mathrm{MC}}\left(\mathrm{W}=0,766<\mathrm{W}_{\text {critical }}\right)$. Two exceptions to the normal distribution were $\mathrm{f}_{\mathrm{ctm}}(\mathrm{W}=0,942$ $\left.>\mathrm{W}_{\text {critical }}\right)$ and $\mathrm{f}_{\mathrm{fl}}\left(\mathrm{W}=0,962>\mathrm{W}_{\text {critical }}\right)$. Therefore, it may be concluded that the multiple regression could not be successfully used, and so it was necessary to apply a more advanced method.

\subsubsection{REGRESSION ANALYSIS}

During regression analysis, splitting tensile strength $f_{c t m}$ and flexure strength $f_{\mathrm{fl}}$ were dependent variables. Compressive strength as an independent variable was provided in the form of different functions: $f_{c}, \sqrt{f_{c}}, \sqrt[3]{f_{c}}, \sqrt[3]{f_{c}^{2}} \ln \left(f_{c}\right), 1 / f_{c}, f_{c}^{2}, f_{c}^{3}, f_{c}^{4}, f_{c}^{5}, f_{c}^{6}, f_{c}^{7}, f_{c}^{8}, f_{c}^{9}, f_{c}^{10}$.In search of the best fit between the regression function and the test data $f_{c t m}$ and $f_{f l}$ the Multiple Regression Method and the Generalized Additive Method were used. The mean absolute percentage error MAPE was calculated through Eq. (4.1):

$$
M A P E=\frac{1}{n} \sum_{i=n}^{T} \frac{\left|Y_{i}-Y_{i p}\right|}{Y_{i}} \cdot 100
$$

where:

$\mathrm{T}$ - calculation and forecast periods total number, $\mathrm{n}$ - forecast periods number, $\mathrm{Y}_{\mathrm{i}}$ - the actual value of the variable in the period $\mathrm{i}, \mathrm{Y}_{\mathrm{ip}}$ - the prediction value of the variable in period $\mathrm{i}$.

First, the Multiple Regression Method was applied, MR1( $\left.f_{c t m}\right), \operatorname{MR} 2\left(f_{c t m}\right) \operatorname{MR} 1\left(f_{f l}\right), \operatorname{MR} 2\left(f_{f l}\right)$. In this method dependent variables $\mathrm{f}_{\mathrm{ctm}}$ and $\mathrm{f}_{\mathrm{fl}}$ were analyzed as functions of compressive strength: $\sqrt[3]{f_{c}^{2}}$, $\sqrt{f_{c}}$ and $\ln \left(1+0,1 \cdot f_{c}\right)$. These functions were used because of their existence in considered codes. The obtained results (MAPE on the level of $8 \%$, adjsted $\mathrm{R}^{2}$ around 0,57 and residual number not in white noise) showed that none of the obtained equations were the regression equation.

In the next step, the Generalized Additive Method GAM was used. In this method, the dependent variable $\mathrm{f}_{\mathrm{ctm}, \mathrm{sp}}$ and $\mathrm{f}_{\mathrm{fl}}$ were analysed with regard to different functions of compressive strength: $f_{c}$, $\sqrt{f_{c}}, \sqrt[3]{f_{c}}, \sqrt[3]{f_{c}^{2}} \ln \left(f_{c}\right), 1 / f_{c}, f_{c}^{2}, f_{c}^{3}, f_{c}^{4}, f_{c}^{5} f_{c}(\mathrm{w} / \mathrm{c})$. The obtained results are presented below, as: 
regression equation Eq. (4.2) Eq. (4.3) and the mean absolute error:MAPE $\left(\operatorname{GAM}\left(\mathrm{f}_{\mathrm{ctm}} ; \sqrt{f_{c}}, \sqrt[3]{f_{c}^{2}}, \mathrm{f}_{\mathrm{c}}\right.\right.$ $(\mathrm{w} / \mathrm{c}))=2,99732 \% ; \operatorname{MAPE}\left(\operatorname{GAM}\left(\mathrm{f}_{\mathrm{fl}} ; \sqrt{f_{c}}, \sqrt[3]{f_{c}^{2}}, \mathrm{f}_{\mathrm{c}}(\mathrm{w} / \mathrm{c}), \mathrm{f}_{\mathrm{c}}(\mathrm{c} / \mathrm{w})\right)=1,94177 \%\right.$.

$$
\operatorname{GAM}\left(f_{c t m} ; \sqrt{f_{c}}, \sqrt[3]{f_{c}^{2}}, f_{c}(\mathrm{w} / \mathrm{c})\right)=2,46621 \sqrt{f_{c}}-1,26418 \sqrt[3]{f_{c}^{2}}+0,04223 f_{c}(\mathrm{w} / \mathrm{c})
$$

where:

$\mathrm{f}_{\mathrm{ctm}}$ - mean value of axial tensile strength of concrete [MPa], $\mathrm{f}_{\mathrm{ck}}$ - characteristic compressive cylinder strength of concrete at 28 days [MPa], $\mathrm{w}$-water content in $1 \mathrm{~m}^{3}$ of concrete [kg], c-cement content in $\mathrm{kg} / \mathrm{m}^{3}$

$$
\operatorname{GAM}\left(f_{f l} ; \sqrt{f_{c}}, \sqrt[3]{f_{c}^{2}}, f_{c}\left(\frac{\mathrm{w}}{\mathrm{c}}\right)\right)=0,402386 \sqrt{f_{c}}-0,028030 \sqrt[3]{f_{c}^{2}}+0,005047 f_{c}\left(\frac{\mathrm{w}}{\mathrm{c}}\right)-0,006584 f_{c}\left(\frac{\mathrm{c}}{\mathrm{w}}\right)
$$

where:

$f_{f l}$ - mean flexural tensile strength of concrete [MPa], $f_{c k}$ - characteristic compressive cylinder strength of concrete at 28 days [MPa], w -water content in $1 \mathrm{~m}^{3}$ of concrete $[\mathrm{kg}], \mathrm{c}-$ cement content in $1 \mathrm{~m}^{3}$ of concrete $[\mathrm{kg}]$

Equations (4.2) (4.3) are regression equations. The residual number RGAM is in a white noise. A very small mean absolute percentage error was obtained. These equations were applied to the next step of statistical analysis, in which the test data was compared with the design values.

\subsection{COMPARATIVE STATISTICAL ANALYSIS}

The analysis of the splitting tensile and flexure tensile strength of the concrete focusing on determining the efficiency of the design methods provided in the different codes according to these two parameters was done (Fig.3). MAPEs analysis is presented in Table 1.

Table 1. MAPE values for comparison of regression equations determined for values obtained experimentally with values obtained by applying the formulas given in the standards

\begin{tabular}{|c|c|c|}
\hline & $\mathrm{f}_{\mathrm{ctm}}$ & $\mathrm{f}_{\mathrm{fl}}$ \\
\hline Eurocode 2 & $13,86 \%$ & $9,84 \%$ \\
\hline $\begin{array}{c}\text { Model Code } \\
2010\end{array}$ & $9,14 \%$ & $10,10 \%$ \\
\hline ACI 318 & $10,80 \%$ & $17,82 \%$ \\
\hline
\end{tabular}



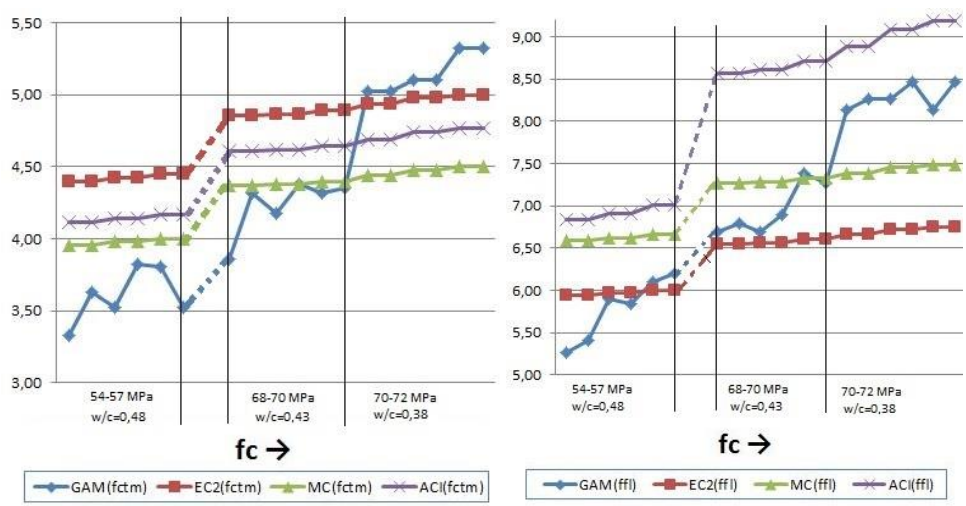

Fig. 3. Tensile (left side) and flexural (right side) strength depending on the compressive strength and w/c

A comparison of the obtained expression with formulas from present standards shows that current dependences differ from dependences in standards, apart from fact that this experimental work possessed a narrow range of concrete characteristics. Maximal deviation was app. 15\%. Usage of standard formulas can prevent under- or over- estimation of prediction concrete characteristics.

\section{CONCLUSiOnS}

Though the design formulas for splitting tensile and flexural strength from different codes presented in this paper differ from each other, all correlate tensile and flexural strength only with compressive strength. The performed statistical study has shown that the regression equation for selected experimental observations cannot be successfully formed on their basis. Regression equations (4.2) and (4.3) correlate the results of splitting tensile and flexural strength with compressive strength, but also with water/cement ratio.

The comparison of the obtained regression equations (4.2) (4.3) with the design formulas from the considered codes shows that the smallest value of the mean absolute percentage error for the splitting tensile strength was obtained via the formula from Model Code 2010 [3] and for the flexural strength via the formula from Eurocode 2 [2]. It must be noticed that for compressive strength under the level of $70 \mathrm{MPa}$ splitting tensile strength from every considered code is overestimated, and this could endanger the safety of construction elements.

Tests and analyses shown in the paper have proved that associations between compressive and tensile/flexural strengths given by all considered standards are not all-purpose serviceable. They 
could lead to under- or over- estimation in predicting concrete characteristics. In the authors opinion it is reasonable to verify the tensile/flexural strength in laboratory tests.

\section{REFERENCES}

1. ACI Committee 318, Building Code Requirements for Structural Concrete (ACI 318-02) and Commentary (ACI 318R-02), American Concrete Institute, 2002.

2. EN 1992-1-1:2004, Eurocode 2: Design of concrete structures. Part 1: General rules and rules for buildings, European Committee for Standardization, 2004.

3. Model Code 2010 - Final draft, Volume 2, Bulletin 66, 2012.

4. J.M. Rapheal, Tensile Strength of Concrete, Jurnal Proceedings, Vol. 81, Issue 2, 1984.

5. I. Narrow, E. Ullberg, Correlation Between Splitting Strength and Flexural Strength of Concrete, Journal Proceedings, Vol.60, Issue 1, 1963.

6. EN 12390-3:2010, Testing hardened concrete. Part 3: Compressive strength of test specimens, European Committee for Standardization, 2010.

7. EN 12390-6:2010, Testing hardened concrete. Part 6: Tensile splitting strength of test specimens, European Committee for Standardization, 2010.

8. P. Woyciechowski, M. Piotrowicz, Ocena wpływu klasy pielęgnacji na wybrane cechy eksploatacyjne betonu, Materiały Budowlane ,2 (498), Warszawa, 2014.

9. EN 12390-5:2010, Testing hardened concrete. Part 5: Flexural strength of test specimens, European Committee for Standardization, 2010.

10. L.S. Aiken, S.G. West, Multiple regression: Testing and interpreting interactions, Sage Publications, USA, 1996.

11. T.J. Hestie, R.J. Tibshirani, Generalized additive models, Chapman Hall, London, 1990.

12. G.E. Box, D.A. Pierce, Distribution of residual autocorrelations in autoregressive integrated moving average time series models, Journal of the American Statistical Association, vol.65, Boston, 1970.

13. M.Słowik, M. Rogalska, The statistical analysis of design methods efficiency in determining shear capacity of reinforced concrete beams, Proceedings of the 11th International Probabilistic Workshop, Brno, 2013.

14. S.S. Shapiro, M.B. Wilk., An analysis of variance test for normality, complete samples., Biometrica, vol.54, Great Brittan, 1965. 


\section{LIST OF FIGURES AND TABLES:}

Fig. 1. Tensile splitting (left side) and flexural (right side) vs. compressive strength acc. to different codes Rys. 1. Wytrzymałości na rozłupywanie (lewa strona) i zginanie (prawa strona) vs wytrzymałość na ściskanie wg norm

Fig. 2. Splitting tensile and flexure strength versus compressive strength of concrete for experimental data Rys. 2. Wytrzymałość na rozciąganie i zginanie, a wytrzymałość na ściskanie dla wartości doświadczalnych Fig. 3. Tensile (left side) and flexural (right side) strength depending on the compressive strength and w/c Rys. 3. Wytrzymałość na rozciąganie (lewa strona) i zginanie (prawa strona) w zależności od wartości wytrzymałości na ściskanie oraz współczynnika w/c

Tab. 1. MAPE values for comparison of regression equations determined for values obtained experimentally with values obtained by applying the formulas given in the standards

Tab. 1. Wartości MAPE dla porównania równań regresji otrzymanych dla wartości otrzymanych doświadczalnie $\mathrm{z}$ wartościami otrzymanymi na podstawie formuł zawartych w normach 


\section{ANALIZA STATYSTYCZNA EFEKTYWNOŚCI METOD PROJEKTOWYCH PRZEWIDYWANIA WYTRZYMALOŚCI NA ROZCIĄGANIE I ZGINANIE BETONÓW WYSOKOWARTOŚCIOWYCH}

Słowa kluczowe: beton wysokowartościowy, wytrzymałość na rozciąganie, wytrzymałość na zginanie, efektywność metod projektowych

\section{STRESZCZENIE:}

Gdy naprężenie w betonowym elemencie konstrukcji przekracza granicę wytrzymałości na rozciąganie trwałość konstrukcji ulega zachwianiu. Jest to spowodowane ekspozycją zbrojenia na czynniki korozyjne. Betony wysokowartościowe (BWW) są coraz częściej wykorzystywane do wykonywania odpowiedzianych elementów obiektów budowlanych, gdzie trwałość jest jednym z kluczowych czynników. Szersze badania i analizy wydają się być uzasadnione, gdyż BWW różni się znacząco od betonu zwykłego.

Celem artykułu jest analiza efektywności metod projektowych proponowanych w różnych normach. Związki pomiędzy wytrzymałością na rozciąganie a wytrzymałością na ściskanie proponowane przez trzy normy (Eurocode 2, ACI 318, Model Code 2010) zostały porównane z wynikami tych wytrzymałości uzyskanymi w sposób doświadczalny za pomocą narzędzi statystycznych.

Wszystkie trzy z analizowanych norm uzależniają wynik wytrzymałości na rozciąganie oraz wytrzymałości na zginanie jedynie od klasy wytrzymałości na ściskanie. Eurocode 2 oraz Model Code 2010 rozróżniają zależność wytrzymałość na rozciąganie - wytrzymałość na ściskanie na zalecaną do stosowania dla klas betonu równą lub poniżej C50/60 oraz powyżej C50/60. Co sugerowałoby różny charakter zależności dla betonów wysokowartościowych.

Normy te rozgraniczają zależności wytrzymałości na rozciąganie a wytrzymałością na ściskanie na klasie wytrzymałości betonu, która jest zmienną klasyfikującą a nie liczbową. W związku z tym w celu oszacowania wartości granicznej rozwiązano układ równań i otrzymano wynik 49,7 MPa. Po przekroczeniu tej wartości przyrost wytrzymałości na rozciąganie jest mniejszy. Zależność dla wytrzymałości na zginanie jest analogiczna. ACI 318 podaje jedną zależność dla wszystkich wytrzymałości na ściskanie betonu.

Ogólny charakter tych norm nie bierze pod uwagę różnic cech składników mieszanki betonowej w obrębie jednej klasy wytrzymałości. Przegląd literatury oraz doświadczenie praktyczne potwierdzają konieczność uwzględnienia wpływu składników betonu, takich jak: rodzaj i maksymalny wymiar kruszywa, rodzaj cementu.

W celu statystycznej oceny efektywności proponowanych przez normy zależności wytrzymałości na rozciąganie i na zginanie wyniki otrzymane za pomocą tych metod zostały skonfrontowane z wynikami uzyskanymi w sposób doświadczalny. Analiza została przeprowadzona dla próbek o zróżnicowanym współczynniku w/c $(0,38 ; 0,43 ; 0,48)$. Zawartość cementu $\left(400 \mathrm{~kg} / \mathrm{m}^{3}\right)$ oraz konsystencja (S3) były stałe. Próbki wykonano z cementu CEM I 42,5 N, kruszywa granitowego 2/16, wody wodociągowej oraz piasku wiślanego. W celu uzyskania stałej konsystencji dla różnych składów mieszanki betonowej wykorzystano domieszkę uplastyczniającą. Próbki pozostały w formach przez $24 \mathrm{~h}$, a następnie były pielęgnowane w wodzie przez $27 \mathrm{dni}$.

W celu określenia wytrzymałości na rozciąganie została wykorzystana procedura normy EN 12390-6. Badanie było przeprowadzone na próbkach walcowych oraz sześciennych. W celu określenia wytrzymałości na zginanie została wykorzystana procedura normy EN 12390-5. Badanie zostało przeprowadzone w próbie zginania jednopunktowego oraz dwupunktowego. W wyniku wstępnej analizy statystycznej wykazano, że wyniki otrzymywane dla różnych kształtów próbek - w przypadku rozciągania, oraz sposobu obciążenia- w przypadku zginania nie są statystycznie 
różne. Właściwa analiza statystyczna była przeprowadzona w dwóch krokach: ustalenie równania regresji dla zmiennych zależnych wytrzymałości na rozciąganie i zginanie oraz porównaniu go z formułami zawartymi w normach. Analizy statystyczne zostały przeprowadzone w programie Statistica StatSoft. Zostały zastosowane: analiza regresji wielorakiej oraz analiza uogólnionych modeli addytywnych. Uzyskane równania regresji zostały wykorzystane w następnym kroku jakim było porównanie ich z modelami zawartymi w normach.

Formuły projektowe zawarte $\mathrm{w}$ normach analizowanych $\mathrm{w}$ artykule różnią się od siebie, jednakże każda z nich uzależnia wytrzymałości na rozciąganie i zginanie jedynie od wytrzymałości na ściskanie. Przeprowadzone analizy statystyczne wykazały iż nie ma możliwości stworzenia równania regresji tylko na podstawie wartości wytrzymałości na ściskanie. Uzyskane równania regresji wiążą wytrzymałość na rozciąganie i zginanie z wytrzymałością na ściskanie, ale również ze współczynnikiem w/c.

Porównanie uzyskanych równań regresji z formułami projektowymi rozważanych norm wykazały iż najmniejszy średni bezwzględny błąd procentowy dla wytrzymałości na rozłupywanie został uzyskany dla formuły z Model Code 2010, natomiast dla wytrzymałości na zginanie dla formuły z Eurocode 2.

Największy średni bezwzględny błąd procentowy dla wytrzymałości na rozłupywanie został uzyskany dla formuły z Eurocode 2, natomiast dla wytrzymałości na zginanie dla formuły z ACI 318

Należy zauważyć, że dla wytrzymałości na ściskanie poniżej $70 \mathrm{MPa}$ wytrzymałość na rozciąganie dla każdej z rozpatrywanych norm jest przeszacowana, co może stanowić zagrożenie dla bezpieczeństwa elementów konstrukcyjnych.

Badania i analizy dowodzą, że związek wytrzymałości na ściskanie z wytrzymałością na rozciąganie/zginanie nie są uniwersalne. Mogą one prowadzić do niedostatecznego lub nadmiernego szacowania. Zasadne wydaje się dodatkowe laboratoryjne sprawdzenie wytrzymałości na rozciąganie i na zginanie. 
